\title{
A New Approach to the Analysis of Numeric Series of 100 R-R Intervals Duration in Studying Heart Rate Dynamics
}

\author{
DOI: $10.17691 / \mathrm{stm} 2015.7 .4 .16$ \\ Received December 22, 2014
}

A.S. Denisov, Engineer, Department of Biomedicine ${ }^{1}$;

V.I. Borisov, MD, DSc, Professor, Department of General Clinical Pharmacology2;

E.E. Volkova, Student, Biological Faculty';

N.V. Vdovina, PhD, Associate Professor, Department of Biomedicine ${ }^{1}$

${ }^{1}$ Lobachevsky State University of Nizhni Novgorod, 23 Prospect Gagarina, Nizhny Novgorod, 603950

Russian Federation;

${ }^{2}$ Nizhny Novgorod State Medical Academy, 10/1 Minin and Pozharsky Square, Nizhny Novgorod, 603005

Russian Federation

The aim of the investigation was to assess a new approach to the analysis of variations in 100 successive $R-R$ intervals duration in determining heart rate dynamics variants during an orthostatic test.

Materials and Methods. Electrocardiogram was recorded and duration of $100 \mathrm{R}-\mathrm{R}$ intervals following each other was measured during an orthostatic test in 74 healthy children aged $12.8 \pm 0.16$ years, 34 of which were training to play football during $1.5-2$ years. While processing numeric series of $100 \mathrm{R}-\mathrm{R}$ intervals we were the first to apply color coding of each value, including those corresponding to the "true" heart rate (THR) parameter. For this purpose, having divided the region of $R-R$ interval values from 0.35 to 1.25 into i spaces by $0.15 \mathrm{~s}$, each interval value depending on its belonging to $i$, as well as $R-R$ intervals corresponding to THR, were marked by a certain color. A THR parameter was determined by a known empirical equation (118.1-0.57a) beats per minute, where $a$ is age in years. Evaluating the whole set of parameters: mode $(\mathrm{Mo}, \mathrm{s})$ - the most frequently occurring $\mathrm{R}-\mathrm{R}$ interval duration; mode amplitude (AMo) - a number of Mo value repetitions - some of which were used in cardiointervalography for the first time (a total quantity of $i$ spaces, in which $R-R$ interval variations occurred - $i_{i}$; the quantity of transitions from one space i to another $-\mathrm{N}_{\text {abs }}$; R-R duration corresponding to THR).

Results. The approach developed made it possible to present clearly the change of the heart rate in time, to assess quantitatively the heart rate dynamics in time and determine the variants of its alteration in the orthostatic test. Their set in healthy children with a high level of physical activity has been found to be similar, though the ratio of diverse variants is different: in changing over to orthostasis cases of a weak influence of the vegetative nervous system on the heart rate occur more often in the young football players than in children with a lower physical load.

Conclusion. Application of color coding of the R-R intervals succession and assessment of the suggested set of parameters for heart rate variability investigation make it possible to present clearly heart rate dynamics and evaluate activity intensity of various parts of the vegetative nervous system without conversion of the numeric series of $R-R$ interval succession to the analog form. The software for automated processing of the investigated data, created on the basis of the algorithm suggested by us, provides the opportunity to assess a vegetative control of the heart rate in various groups under investigation.

Key words: heart rate variability; $100 \mathrm{R}-\mathrm{R}$ intervals; orthostatic test.

The possibility to assess the intensity of various effects on the heart activity by the character of the heart rate variability continues to attract attention to cardiointervalography (CIG). This method requires no complicated technical solutions, large economic expenses, and it is safe and convenient for screening investigations. Application of $\mathrm{CIG}$ is proved to be perspective for evaluating the balance of different parts of the vegetative nervous system (VNS) in various body states: cardiovascular diseases [1], neurological illnesses [2, 3], pregnancy [4], infectious diseases [5], in diverse age groups and different levels of physical activity, e.g. in doing different kinds of sports $[6,7]$. Various approaches to processing data on the duration of R-R intervals following each other and result presentation are used in CIG. Some investigators, for example, perform statistical processing of sampled values of $R-R$ interval duration (usually no less than 100 following each other R-R intervals) and analyze the set of such parameters as mode (Mo) - the most frequently occurring $R-R$ interval values; Mo amplidute (AMo) - the quantity of R-R intervals in the sample, having duration equal to Mo; range of variations $(\mathrm{V})$ the difference between the largest and smallest value of $\mathrm{R}-\mathrm{R}$ interval duration in the given sample, and others. Moreover, the data in the studied R-R interval samples are presented in the analog form. These are histograms reflecting the rhythm structure: the quantity of $R-R$ intervals of various duration [1, 8, 9] and spectrograms obtained by the spectral analysis using Fourier transformation of data on R-R interval duration over a long period of time (from several minutes to several

For contacts: Vdovina Nataliya Vsevolodovna, e-mail: nataliya.vdovina@mail.ru 
hours) [8-11]. Data on alteration of $R-R$ interval duration in time (heart rate dynamics) is presented in the form of rhythmograms, on which duration of each of the R-R intervals is recorded, or as scaterograms [9-11]. Though these approaches to CIG results processing enable the evaluation of vegetative regulation of the rhythm in different cohorts, none of them takes into consideration the age characteristics of impulse-generator sells of the main heart rate pacemaker - the sinoatrial node (SAN) and their interaction with regulatory effects of VNS. And, at the same time, heart rate changes and correlation of various VNS parts activity in the course of ontogenesis are well known.

Having started with the known methods of data processing while studying the heart rate dynamics in children with a high level of health and physical activity $[3,7]$, we came to the conclusion that it is possible to increase the visual presentation of the heart rate dynamics and intensity of regulatory effects of various VNS parts on it. Our approach to the analysis of numeric series of $100 \mathrm{R}-\mathrm{R}$ intervals following each other allows the visual presentation of each $R-R$ interval duration and its alteration in the period of examination without presentation of the results in the analog form. Additionally, we supposed, that it is possible to improve the informativity of CIG by considering the so called true heart rate (THR), characterizing age specificity of SAN pacemaker cells. This rate can be determined by an empiric equation (118.1-0.57a) beats per minute, where $a$ is the age of the examined person [12]. Outlining the $R-R$ intervals, the duration of which corresponds to THR, it is possible to visually present and analyze alterations in time and intensity of the effects of various VNS parts on the heart rate, as well as the ability to regulate (the response to the regulatory effects) the SAN cells, and, possibly, specific organization of SAN cell pacemaker activity.

Presently there appeared data on "heterogeneity" of the SAN cells $[5,13,14]$. The membrane cell structure of various SAN regions was found to differ by the presence of proteins and their proportion, performing different functions: receptors, channel-formers, ion pumps, and antiporters. The ability of SAN cells to interact with various neuromediators, permeability of their biological membrane, duration of the action potential phases (AP), generated by them, depend on these substances. The heart rate in some time intervals is thought to be set by a "leading pacemaker site" - this is a group of SAN cells, generating AP, propagating along the SAN and other parts of the conductive system of the heart, causing it to contract. Various ensembles of SAN cells are supposed to perform the function of the "leading pacemaker site", which migrates depending, in particular, on the activity of different parts of the VNS.

The heart rate is known to change in ontogenesis. It is associated with the age dynamics of the functional state of different parts of the VNS. At the same time,
THR, observed under the action of receptor blockers of different parts of the VNS, also changes, which is likely to be connected with alterations in the ontogenesis of the cell membrane structure of different SAN regions. In other words, the intensity of regulatory VNS effect depends on the age or, probably, on the individual SAN structure, and on the interaction of SAN pacemaker cells with each other and VNS neuromediators.

These findings made us suppose, that selecting time spaces, in which duration of R-R intervals corresponds to the THR (i.e. time spaces in which the effects of VNS are minimal) during investigation of the heart rate time dynamics, it will be possible to evaluate individual changes in time occurring under the influence of different parts of VNS in time, which is likely to improve CIG informativity.

The aim of the investigation was to assess the efficiency of the developed approach to the heart rate analysis and, using orthostatic test, to determine the variants of heart rate dynamics in school-year children with a high level of physical activity.

Materials and Methods. Digital records of electrocardiograms (ECG) were obtained in 74 healthy children at the age of 10-16 years. Two groups of children with a different level of physical activity were formed. Group $1(n=40)$ included children, the ECG in which was taken in a summer health camp (average age $13.3 \pm 0.22$ years). Group 2 comprised 34 children (average age $12.2 \pm 0.19$ years). The children of this group attended football club in a children's sports school. They were engaged in this kind of sport for 1.5-2 years. In group 2 ECG was recorded 20-30 min before training.

The study complies with the Declaration of Helsinki (the Declaration was passed in Helsinki, Finland, June, 1964, and revised in October, 2000, Edinburg, Scotland) and was performed following approval by the Ethic Committee of Lobachevsky State University of Nizhny Novgorod. Written informed consent was obtained from patients' parents.

In both groups ECG was registered using a device for electrophysiological investigations MP-36 (BIOPAC Systems, Inc., USA), mated to a personal computer [15]. The leads were located on the wrist of the right upper limb and ankles of both lower limbs (standard lead II). ECG was recorded first for 2-3 min in the child lying supine, thereafter for 2-3 min immediately after the transition to the standing position (orthostasis). The device software enabled ECG digital recording. On the digital record (300 measurements per second), characterizing a change of the total electric heart activity in time, peaks of the body surface electrical potentials, corresponding to ECG R-waves were selected, and the duration of 100 following each other $\mathrm{R}-\mathrm{R}$ intervals was measured (in seconds).

The results were recorded in Excel program in the form of a numeric series of $R-R$ interval values. And depending on the interval duration each cell in the 


\begin{tabular}{|c|c|c|c|c|c|c|c|c|c|c|c|c|c|}
\hline 1 & 2 & 3 & 4 & 5 & 6 & 7 & 8 & 9 & 10 & 11 & 12 & 13 & \multirow[b]{2}{*}{$\cdots$} \\
\hline 0.83 & 0.82 & 0.81 & 0.75 & 0.69 & 0.71 & 0.96 & 0.91 & 0.76 & 0.85 & 0.76 & 0.80 & 0.89 & \\
\hline \multirow[t]{2}{*}{$\cdots$} & 88 & 89 & 90 & 91 & 92 & 93 & 94 & 95 & 96 & 97 & 98 & 99 & 100 \\
\hline & 0.78 & 0.80 & 0.88 & 0.81 & 0.71 & 0.88 & 0.83 & 0.69 & 0.71 & 0.77 & 0.76 & 0.72 & 0.82 \\
\hline
\end{tabular}

a

\begin{tabular}{c|c|c|c|c|c|c|c|c|c|c|c|c|c|c|}
\hline 1 & 2 & 3 & 4 & 5 & 6 & 7 & 8 & 9 & 10 & 11 & 12 & 13 & \\
\hline 0.53 & 0.54 & 0.55 & 0.57 & 0.54 & 0.52 & 0.55 & 0.56 & 0.59 & 0.54 & 0.57 & 0.57 & 0.57 & $\ldots$ \\
$\ldots$ & 88 & 89 & 90 & 91 & 92 & 93 & 94 & 95 & 96 & 97 & 98 & 99 & 100 \\
\cline { 2 - 12 } & 0.61 & 0.59 & 0.60 & 0.53 & 0.55 & 0.57 & 0.53 & 0.59 & 0.55 & 0.58 & 0.59 & 0.60 & 0.59 \\
\hline
\end{tabular}

Numeric series of duration of 100 R-R intervals in a lying (a) and in a standing (b) position; the upper line shows the number of R-R interval, the lower line - duration in seconds

column (line) of the numeric series of $100 \mathrm{R}-\mathrm{R}$ intervals was automatically marked by a definite color (See the Figure). Based on the fact, that the difference between the largest and the smallest values of $R-R$ intervals not less than $0.15-0.16 \mathrm{~s}$ [9] may be the evidence of sinus arrhythmia, and considering the data obtained by us in these and previous studies [7, 16], which show that all the values of $\mathrm{R}-\mathrm{R}$ intervals in the examined children of both groups in a lying and standing positions are in the range of $1.25-0.35 \mathrm{~s}$, we divided the area from 1.25$0.35 \mathrm{~s}$ into spaces (i) by $0.15 \mathrm{~s}$. If $\mathrm{R}-\mathrm{R}$ duration was not less than $1.1 \mathrm{~s}$ (space i1), the cells were colored white, cells with $R-R$ values from 1.09 to $0.95 \mathrm{~s}$ (i2) in yellow, with the values from 0.94 to $0.8 \mathrm{~s}$ (i3) in green, and from 0.79 to $0.65 \mathrm{~s}$ (i4) in blue. Since in the next interval $0.15 \mathrm{~s}$ - there was the majority of R-R duration values in the standing position, two regions were marked in it: from 0.64 to $0.58 \mathrm{~s}$ (i5) was gray, and from 0.57 to $0.5 \mathrm{~s}$ (i6) was colored red. The cells with $R-R$ values not more than $0.49 \mathrm{~s}$ (i7) were marked by a violet, and values corresponding to THR by an orange color.

"Standard" parameters, accepted in CIG, were used for quantitative analysis of numeric series of $100 \mathrm{R}-\mathrm{R}$ intervals, as well as the parameters, characterizing the dynamics of $R-R$ interval value transition to different 0.15 -second spaces of their variation, which are suggested to be used for investigation of the heart rate pattern changes in time [16].

Duration of $100 \mathrm{R}-\mathrm{R}$ intervals $\left(\sum 100 \mathrm{R}-\mathrm{R}, \mathrm{s}\right)$, mode (Mo, s) as the most frequent R-R interval value, and AMo were determined by numeric series of $R-R$ intervals in the lying and standing positions. To define AMo, each of the i spaces was divided into $0.05 \mathrm{~s}$ sections [8] and the number of R-R intervals, being in the same $0.05 \mathrm{~s}$ interval as $\mathrm{Mo}(\mathrm{Mo} \pm 0.25 \mathrm{~s})$, were calculated.

It was for the first time in CIG that such parameters as $\mathrm{i}_{\mathrm{t}}, \mathrm{N}_{\mathrm{abs}}, \mathrm{N}$ and $\mathrm{R}-\mathrm{R}_{\mathrm{THR}}$ were calculated. Parameter $\mathrm{i}_{\mathrm{t}}$ designates the number of spaces with $0.15 \mathrm{~s}$ duration within which variation of $R-R$ interval occurred. Its assessment allows not only the evaluation of $R-R$ interval variation range, but enables one to find alterations of their variation area in different conditions. Parameter $\mathrm{N}_{\mathrm{abs}}$ means the number of transitions from one i space to the other, including the transition between i5 and i6 spaces. In the area of $\mathrm{N}_{\mathrm{abs}}$ value change, 8 intervals were outlined and $\mathrm{N}$ parameter was determined. If from 2-5 to 10 transitions from one i interval to another was observed in $100 \mathrm{R}-\mathrm{R}$ record, $\mathrm{N}$ was considered equal to 1 . When there were 11-20 transitions, $\mathrm{N}$ was equal to 2, and so on up to $\mathrm{N}=8$, when the number of transitions exceeded 71 . Additionally, the ratio $\mathrm{N}_{\mathrm{abs}} / \sum 100 \mathrm{R}-\mathrm{R}$ was calculated, indirectly reflecting the frequency $(\mathrm{Hz})$ of $\mathrm{R}-\mathrm{R}$ transitions to various i spaces. $R-R_{T H R}$ was determined by a formula $60 / T H R$. So, a set of several parameters was obtained for each numeric series of $R-R$ values and their values were compared in the lying and standing position.

In qualitative analysis of the numeric series of 100 $R-R$, the presence of $R-R$ with $R-R_{T H R} \pm 0.025-0.003 \mathrm{~s}$ duration was considered to testify the absence (or a very weak intensity) of VNS effect. In children of the examined age group it was, on average, corresponded to the range of $0.545 \pm 0.025 \mathrm{~s}$. Time fragments, in which $R-R$ duration was more than $R-R_{T H R}-0.025 \mathrm{~s}$ were supposed to show the influence of parasympathetic nervous system (PSNS) on the heart rate. It was considered, that at Mo being in the space i1-2, PSNS effect is very intensive, at Mo in i3 it is less marked, in i4 the effect is moderate, and at Mo in i5 the influence of PSNS is weak. Time fragments, in which the duration of $R-R$ intervals was less than $0.52 \mathrm{~s}$ were estimated to be the periods of intensive influences of the sympathetic nervous system (SNS).

To compare the parameters characterizing heart rate 
variability, the following methods were used: parametric statistical methods (calculation of means, their errors, testing the hypothesis on the presence of the quantitative sample differences using Student's criterion, calculation of the paired correlation coefficient for the samples of evaluated parameters) and non-parametric ones, designed for small samples — Fisher's exact test (FET) [17]. Non-parametric methods were applied for the assessment of sample parameter differences, formed by Mo values in the lying position $\left(\mathrm{Mo}_{\mathrm{L}}\right)$ in a certain space $\mathrm{i}$ (Mo in i1-2, i3, i4, i5-6, i7).

Results and Discussion. Mean arithmetic values of Mo, $\sum 100 \mathrm{R}-\mathrm{R}, \mathrm{N}\left(\mathrm{N}_{\mathrm{abs}}, \mathrm{N}_{\mathrm{abs}} / \sum 100 \mathrm{R}-\mathrm{R}\right)$ were larger, and AMo smaller in both groups in a lying position than in a standing (the significance level of differences of the means ( $p$ ) according to Student's t-test not less than 0.05). Mean values of $i_{t}$ only in group 1 in the lying position were significantly larger $(p \leqslant 0.05)$ than in the standing position. When comparing individual parameter changes in different body positions, the transition to orthostasis was found to be accompanied by the decrease of Mo, $\mathrm{i}_{\mathrm{t}}, \mathrm{N}$ and increase of AMo in $32 \%$ of children in group 1 and $29 \%$ of children in group 2 . The Mo parameter in $92 \%$ of all examined children (95\% in group 1 and $88 \%$ in group 2) decreased in standing up by not less than $0.05 \mathrm{~s}$. $\mathrm{N}$ parameter in standing up also diminished in $73 \%$ of children. In $12 \%$ of children it retained its meaning in orthostasis (it differed by not more than 10 transitions from one $i_{t}$ to another), whereas it increased in $15 \%$ in the standing position. In the transition to the standing position $\mathrm{i}_{\mathrm{t}}$ parameter did not change in $37 \%$ of children, decreasing in 49\%, and increasing in 14\%. And, as a rule, if $i_{t}$ value in both body positions was equal, in the standing position the spaces of $\mathrm{R}-\mathrm{R}$ variation were shifted to the area of smaller values. For example, $i_{t}$ in both positions is equal to 3 , but in the lying position R-R varies in the spaces i2-i4, while in the standing position the variation is in i3-i5-6 or i4-i7. AMo parameter increased in $60 \%$ of children in transition to the standing position, did not change (differed by not more than 5 ) in $30 \%$, and decreased in $20 \%$ of children.

As Mo parameter is the most frequently repeated result of diverse regulatory effects on the SAN cells, it may be used for assessing the intensity of the effects of various parts of VNS on the heart rate, we decided, that Mo in i1-2 is an evidence of the strong effects of PSNS, at Mo in i3 they are less strong, in i4 they are moderate, and in i5 PSNS effects are found to be weak. In the lying position Mo was in i3 more often in group 1 than in group 2 (33 and $21 \%$, respectively), but it was observed more seldom in i4 (40 and 47\%, respectively). The number of children with $\mathrm{Mo}_{\mathrm{L}}$ in $\mathrm{i} 1-2$ and in i5-6 in both groups was approximately the same. For reasons given a conclusion was made, that PSNS effects were most prominent in the lying position in group 1.

Mo distributed over different i approximately equally in the standing position in both groups. In orthostasis $\mathrm{Mo}_{\mathrm{S}}$ was more often in i6 in $38 \%$ of all children; in i5 in $27 \%$; in i4 in 24\%; in i7 in $7 \%$, and in i3 in $4 \%$.

Comparing the samples of parameters at $\mathrm{Mo}_{\mathrm{L}}$ in various spaces, it has been found, that at $\mathrm{Mo}_{\mathrm{L}}$ in i4 the lower AMo values in group 1 occurred more often than in group 2: $<19$ in a lying position and $<36$ in the standing one ( $p=0.05$ according to FET). We assumed, that AMo in a set of $\mathrm{i}_{\mathrm{t}}$ and $\mathrm{N}\left(\mathrm{N}_{\mathrm{abs}}, \mathrm{N}_{\mathrm{abs}} / \sum 100 \mathrm{R}-\mathrm{R}\right)$ parameters may be used as index of the number of "degrees of freedom" of the SAN cells, reflecting an individual migration character of the "leading pacemaking site" of heterogeneous SAN cells, SAN regularity, i.e. the sensitivity to the regulatory VNS effects. Low AMo values at relatively high $\mathrm{i}_{\mathrm{t}}, \mathrm{N}\left(\mathrm{N}_{\mathrm{abs}}, \mathrm{N}_{\mathrm{abs}} / \sum 100 \mathrm{R}-\mathrm{R}\right)$ were estimated to be a "mild" regulation (energetically probably more beneficial), in which VNS effects do not decrease, but in some cases increase the number of SAN cell "degrees of freedom". High AMo values and/or low values of $i_{t}, N\left(N_{a b s}, N_{a b s} / \sum 100 R-R\right)$ were considered the sign of the reduction of SAN cell "degrees of freedom". It may be due to either "tough" regulation, submitting, synchronizing all SAN cells, as at Mo in i1-2 and i3, or, on the contrary, weakening of the regulatory effects of PSNS, as in the areas of R-R interval duration, being a bit less than a "true" SAN rate (Mo in i4, i5). We supposed, that $\mathrm{AMo}$ at Mo, being in the area of $\mathrm{R}-\mathrm{R}$ values close to the "true" SAN rate (Mo in i6), characterizes individual features of SAN cells, e.g. the quantity of cell ensembles able to determine the SAN rate, and at Mo in 7i reflects the intensity of SNS. Therefore, high values of AMo at Mo in i4 in many children of group 2 may speak of the fact, that PSNS effects and migration of the "leading pacemaking site" were less intensive.

At $\mathrm{Mo}_{\mathrm{L}}$ in i5-6 statistically significant $(\mathrm{p}=0.05$ according to FET) samples of $\mathrm{N}, \mathrm{N}_{\mathrm{abs}}, \mathrm{N}_{\mathrm{abs}} / \sum 100 \mathrm{R}-\mathrm{R}$ were found. Thus, in group 2 the lower values of these parameters were encountered more often. So a conclusion can be drawn, that at these Mo values PSNS influence was less intensive in many children of group 2.

Comparison of parameter samples at $\mathrm{Mo}_{\mathrm{L}}$ in different i spaces allowed us to reveal the differences between the groups: in both body positions differences among parameter samples in group 1 occurred more frequently, than in group 2 (Table 1). Besides, in a standing position in group 2 there were prominent differences of parameters at $\mathrm{Mo}_{\mathrm{L}}$ in i4 and $\mathrm{i5}-6$, being absent in group 1.

Differences in the heart rate dynamics present in both groups are also confirmed by the results of investigation of coefficients of paired correlation (Table 2).

Correlation between the majority of parameters in the lying position and in orthostasis in group 2 was more marked than in group 1. Additionally, a correlation between AMo and Mo, $\sum 100 \mathrm{R}-\mathrm{R}, \mathrm{i}_{\mathrm{t}}, \mathrm{N}$ was noted to be low in the lying position in group 2 , whereas in the standing position in this group various parameters correlated more than in group 1. 
Table 1

Statistically significant differences of parameter samples ( $p=0.05$ according to Fisher's exact test) at Mo in the lying position in different i spaces in children with different levels of physical activity

\begin{tabular}{|c|c|c|c|c|c|c|c|c|c|}
\hline \multicolumn{10}{|c|}{ Group 1 - children with a lower physical activity } \\
\hline \multicolumn{6}{|c|}{ A lying position } & \multicolumn{4}{|c|}{ Standing position } \\
\hline \multicolumn{2}{|c|}{ Parameter } & AMo & $i_{t}$ & $\mathbf{N}$ & $\mathrm{N}_{\mathrm{abs}} / \Sigma 100 \mathrm{R}-\mathrm{R}$ & \multicolumn{2}{|c|}{ Parameter } & AMo & $i_{t}$ \\
\hline \multicolumn{2}{|c|}{$\mathrm{D}$} & - & $<4^{\star}$ & $<6^{*}$ & $<0.48^{*}$ & \multicolumn{2}{|c|}{$\mathrm{D}$} & - & $<3^{*}$ \\
\hline $\mathrm{Mo}_{\mathrm{L}}$ in $\mathrm{i}$ & $\mathrm{n}_{\mathrm{t}}$ & \multicolumn{4}{|c|}{$\mathrm{n}_{\mathrm{d}}$} & $\mathrm{Mo}_{\mathrm{L}}$ in $\mathrm{i}$ & $n_{t}$ & \multicolumn{2}{|r|}{$n_{d}$} \\
\hline $1-2$ & 6 & - & 2 & 1 & 1 & $1-2$ & 6 & - & 2 \\
\hline 3 & 13 & - & 10 & 9 & 7 & 3 & 13 & - & 10 \\
\hline \multicolumn{2}{|c|}{ D } & $>34^{*}$ & $<4^{*}$ & $<6^{*}$ & $<0.44^{*}$ & \multicolumn{2}{|c|}{ D } & $<36^{\star}$ & - \\
\hline $\mathrm{Mo}_{\mathrm{L}}$ in $\mathrm{i}$ & $n_{t}$ & \multicolumn{4}{|c|}{$\mathrm{n}_{\mathrm{d}}$} & $\mathrm{Mo}_{\mathrm{L}}$ in $\mathrm{i}$ & $n_{t}$ & \multicolumn{2}{|r|}{$\mathrm{n}_{\mathrm{d}}$} \\
\hline $1-2$ & 6 & 0 & 2 & 1 & 0 & $1-2$ & 6 & 3 & - \\
\hline 4 & 16 & 11 & 13 & 13 & 9 & 4 & 16 & 0 & - \\
\hline \multicolumn{2}{|c|}{ D } & - & $>2^{*}$ & - & $<0.44^{\star}$ & \multicolumn{2}{|c|}{ D } & $<48^{*}$ & - \\
\hline $\mathrm{Mo}_{\mathrm{L}}$ in $\mathrm{i}$ & $\mathrm{n}_{\mathrm{t}}$ & \multicolumn{4}{|c|}{$n_{d}$} & $\mathrm{Mo}_{\mathrm{L}}$ in $\mathrm{i}$ & $\mathrm{n}_{\mathrm{t}}$ & \multicolumn{2}{|r|}{$\mathrm{n}_{\mathrm{d}}$} \\
\hline 4 & 5 & - & 0 & 一 & 0 & 3 & 13 & 2 & 一 \\
\hline $5-6$ & 16 & - & 11 & - & 9 & 4 & 16 & 10 & - \\
\hline \multicolumn{2}{|c|}{ D } & $>34^{*}$ & $>3^{*}$ & $>4^{*}$ & - & \multicolumn{2}{|c|}{ D } & - & $>2^{*}$ \\
\hline $\mathrm{Mo}_{\mathrm{L}}$ in $\mathrm{i}$ & $\mathrm{n}_{\mathrm{t}}$ & \multicolumn{4}{|c|}{$\mathrm{n}_{\mathrm{d}}$} & $\mathrm{Mo}_{\mathrm{L}}$ in $\mathrm{i}$ & $\mathrm{n}_{\mathrm{t}}$ & \multicolumn{2}{|r|}{$n_{d}$} \\
\hline $1-2$ & 6 & 0 & 6 & 1 & - & $1-2$ & 6 & - & 4 \\
\hline $5-6$ & 5 & 5 & 0 & 1 & - & $5-6$ & 5 & - & 0 \\
\hline \multicolumn{10}{|c|}{ Group 2 - sportsmen } \\
\hline \multicolumn{3}{|c|}{ A lying position } & \multicolumn{7}{|c|}{ Standing position } \\
\hline \multicolumn{2}{|c|}{ Parameter } & $\mathbf{N}$ & \multicolumn{2}{|c|}{ Parameter } & AMo & \multicolumn{2}{|c|}{$i_{t}$} & N & $\mathbf{N}_{\mathrm{abs}} / \Sigma 100 \mathrm{R}-\mathrm{R}$ \\
\hline & & $<4^{*}$ & & & $<30^{*}$ & & & - & - \\
\hline $\mathrm{Mo}_{\mathrm{L}}$ in $\mathrm{i}$ & $\mathrm{n}_{\mathrm{t}}$ & $\mathrm{n}_{\mathrm{d}}$ & $\mathrm{Mo}_{\mathrm{L}}$ in $\mathrm{i}$ & $n_{t}$ & & & & & \\
\hline $1-2$ & 6 & 0 & 3 & 7 & 0 & & & - & - \\
\hline 4 & 16 & 19 & 4 & 16 & 8 & & & - & - \\
\hline & & - & & & - & & & $>1^{*}$ & $>0.23^{*}$ \\
\hline $\mathrm{Mo}_{\mathrm{L}}$ in $\mathrm{i}$ & $n_{t}$ & $\mathrm{n}_{\mathrm{d}}$ & $\mathrm{Mo}_{\mathrm{L}}$ in $\mathrm{i}$ & $n_{t}$ & & & & & \\
\hline 4 & 16 & - & 4 & 16 & - & & & 12 & 9 \\
\hline $5-6$ & 5 & - & $5-6$ & 5 & - & & & 1 & 0 \\
\hline & & $>4^{*}$ & & & - & & & $<2^{*}$ & $>23^{*}$ \\
\hline $\mathrm{Mo}_{\mathrm{L}}$ in $\mathrm{i}$ & $n_{t}$ & $\mathrm{n}_{\mathrm{d}}$ & $\mathrm{Mo}_{L}$ in $\mathrm{i}$ & $n_{t}$ & & & & & \\
\hline 1-2 & 6 & 5 & $1-2$ & 6 & 一 & & & 0 & 5 \\
\hline $5-6$ & 5 & 0 & $5-6$ & 5 & - & & & 4 & 0 \\
\hline
\end{tabular}

$\mathrm{N}$ o t e. $\mathrm{D}$ is the parameter value, at which differences between the samples were statistically significant according to Fisher's exact test; $n_{t}$ is the total number of members in the compared samples; $n_{d}$ denotes the number of members in the compared samples, which were more $(>)$ or less $(<)$ than $D ;{ }^{*} p=0.05$. Index $L$ means a lying position.

The revealed differences in correlation coefficients and parameter samples at $\mathrm{Mo}_{\llcorner}$in various i spaces in both groups may be supposed to speak of the presence of differences in vegetative regulation in them. In group 2, for example, the effects of PSNS on SAN at Mo in i4 and i5 in many children are less intensive.

Based on the assumption of the presence of the "true" heart rate we supposed that at the $R-R$ values 
Table 2

Coefficients of paired correlation of parameters, characterizing heart rate variability in children of group $1(n=40)$ and group $2(n=34)$ in the lying and standing position

\begin{tabular}{|c|c|c|c|c|c|c|c|}
\hline \multirow{3}{*}{ Parameters } & \multicolumn{2}{|c|}{ Groups } & \multirow{3}{*}{ Parameters } & \multicolumn{4}{|c|}{ Group } \\
\hline & \multirow{2}{*}{1} & \multirow{2}{*}{2} & & 1 & 2 & 1 & 2 \\
\hline & & & & \multicolumn{2}{|c|}{ Lying } & \multicolumn{2}{|c|}{ Standing } \\
\hline $\mathrm{Mo}_{\mathrm{L}} \leftrightarrow \mathrm{Mo}_{\mathrm{S}}$ & 0.37 & 0.63 & $\mathrm{Mo \leftrightarrow} \mathrm{i}_{\mathrm{t}}$ & 0.55 & 0.45 & 0.47 & 0.75 \\
\hline $\mathrm{i}_{\mathrm{tL}} \leftrightarrow \mathrm{i}_{\mathrm{tS}}$ & 0.26 & 0.44 & $\mathrm{Mo} \leftrightarrow \mathrm{N}$ & 0.56 & 0.58 & 0.21 & 0.64 \\
\hline $\mathrm{N}_{\mathrm{L}} \leftrightarrow \mathrm{N}_{\mathrm{S}}$ & 0.08 & 0.24 & Mo↔AMo & -0.59 & -0.1 & -0.34 & -0.58 \\
\hline $\mathrm{AMo}_{\mathrm{L}} \leftrightarrow \mathrm{AMO}_{\mathrm{S}}$ & 0.1 & 0.58 & Mo↔ $\leftrightarrow 100 \mathrm{R}-\mathrm{R}$ & 0.9 & 0.95 & 0.98 & 0.97 \\
\hline$\Sigma 100 R-R_{L} \leftrightarrow \Sigma 100 R-R_{S}$ & 0.35 & 0.76 & $\mathrm{i}_{\mathrm{t}} \leftrightarrow \mathrm{N}$ & 0.61 & 0.52 & 0.12 & 0.66 \\
\hline & & & $\mathrm{i}_{\mathrm{t}} \leftrightarrow \mathrm{AMo}$ & -0.58 & -0.21 & -0.3 & -0.47 \\
\hline & & & $\mathrm{i}_{\mathrm{t}} \leftrightarrow \Sigma 100 \mathrm{R}-\mathrm{R}$ & 0.64 & 0.53 & 0.53 & 0.78 \\
\hline & & & $\mathrm{N} \leftrightarrow \mathrm{AMo}$ & -0.66 & -0.21 & -0.09 & -0.36 \\
\hline & & & $\mathrm{N} \leftrightarrow \Sigma 100 \mathrm{R}-\mathrm{R}$ & 0.66 & 0.67 & 0.23 & 0.66 \\
\hline & & & $\mathrm{AM} 0 \leftrightarrow \Sigma 100 \mathrm{R}-\mathrm{R}$ & -0.65 & -0.19 & -0.41 & -0.62 \\
\hline
\end{tabular}

$\mathrm{N}$ o t e. Index $\mathrm{L}$ designates a lying position, index $\mathrm{S}$ - a standing position.

corresponding to the THR R- $\mathrm{R}_{\mathrm{THR}}$ (in our examined groups it amounted, on average, to $0.545 \pm 0.025 \mathrm{~s}$ ), there is a high probability of displaying the properties of SAN cells in the heart rate. $7.5 \%$ of children of group 1 were found to have in the records of $100 \mathrm{R}-\mathrm{R}$ episodes with duration of $\mathrm{R}-\mathrm{R}_{\mathrm{THR}}$ in the lying position, and in $82.5 \%$ in the standing position, while in group 2 in 24 and $88 \%$, respectively. It allowed us to draw a conclusion, that in the lying position in group 2 PSNS effects were less intensive in the majority of children, whereas in the standing position the effects of VNS decreases considerably in most examined children of both groups and individual features of the SAN pacemaker cell interrelation are displayed in the heart rate. As far as SNS effects are concerned, episodes with R-R duration less than $0.52 \mathrm{~s}$ were likely to be associated with them. In the lying position they occurred in the records of 100 R-R in $7.5 \%$ of children of group 1 and $12 \%$ of group 2 , and in the standing position in 60 and $88 \%$ of the examined children, respectively. It shows a some what greater intensity of SNS effects in children of group 2 in the standing position, which is likely to be connected with their sports activity or with the fact, that ECG was taken directly before training.

Conclusion. The results obtained speak of the perspectiveness of the suggested approach to the analysis of $100 \mathrm{R}-\mathrm{R}$ interval recording. This approach provides a clear visualization of cardiointervalography results, allows the assessment of individual heart rate dynamics, on-line determination of changes in the intensity and pattern of vegetative heart rate regulation. Application of the suggested set of parameters for heart rate variability evaluation enables the quantitative description of heart rate alterations in time in various cohorts. The algorithm for analyzing numeric series records, developed by us, may be used for designing a software for fully automated processing of investigation results.

Study Funding and Conflicts of Interest. This study was not supported by any financial sources and there is no topic specific conflicts of interest related to the authors of this study.

\section{References}

1. Borisov V.I., Matusova A.P., Mudrova L.A., Reyman A.M. Analiz variabel'nosti serdechnogo ritma $v$ otsenke sostoyanii bol'nykh infarktom miokarda [Analysis of heart rate variability in assessing the state of patients with myocardium infarction]. Nizhny Novgorod: NGMA; 1997.

2. Sokolova N.A., Ivanova N.Ye., Panuntsev V.S., Kozyreva L.V. Evaluation of the vegetative dysfunction using heart rate variability analysis during nontraumatic intracranial hemorrhages. Byulleten' sibirskoy meditsiny 2008; 7(5-2): 385-390.

3. Denisov A.S., Vdovina N.V., Borisov V.I., Radaeva T.M. Variabel'nost' serdechnogo ritma u detey zdorovykh i s nekotorymi nevrologicheskimi zabolevaniyami. V kn.: Materialy $V$ Vserossiyskogo simpoziuma s mezhdunarodnym uchastiem 'Variabel'nost' serdechnogo ritma: teoreticheskie aspekty i prakticheskoe primenenie" [Heart rate variability in healthy children and those having some neurological diseases. In: Materials of V All-Russian Symposium with international participation "Heart rate variability: theoretical aspects and practical application"]. Izhevsk; 2011; p. 411-412.

4. Gudkov G.V., Penzhoyan M.A. New approaches to assessment of pathological dynamics of the heart rate variability 
of a fetus in forecasting perinatal outcomes. Vestnik novykh meditsinskikh tekhnologiy 2009; 16(3): 191-193.

5. Papaioannou V.E., Verkerk A.O., Amin A.S., de Bakker J.M. Intracardiac origin of heart rate variability, pacemaker funny current and their possible association with critical illeness. Curr Cardiol Rev 2013; 9(1): 82-96, http://dx.doi. org/10.2174/157340313805076359.

6. Shlyk N.I., Sapozhnikova E.N., Kirillova T.G., Zhuzhgova A.P. About the peculiarities of orthostatic reaction of sportsmen with different types of vegetative regulation. Vestnik Udmurtskogo universiteta 2012; 6-1: 114-125.

7. Denisov A.S., Vdovina N.V., Borisov V.I. Heart rate variability in different body positions in school-age children with different health and physical activity levels. Vestnik NNGU im. N.I. Lobachevskogo 2013; 5-1: 153-159.

8. Baevskiy R.M., Ivanov G.G., Chireykin L.V., Gavrilushkin A.P., Dovgalevskiy P.Ya., Kukushkin Yu.A., Mironova T.F., Prilutskiy D.A., Semenov A.V., Fedorov V.F., Fleyshman A.N., Medvedev M.M. Analysis of heart rate variability using various electrocardiographic systems. Vestnik aritmologii 2001; 24: 69-85.

9. Rodionov A. Klinicheskoe znachenie issledovaniya variabel'nosti serdechnogo ritma [Clinical value of heart rate variability study]. URL: www.medicus.ru/cardiology/spec/ ?cont=article\&art_id=947.

10. Sobolev A.V. Metody analiza variabel'nosti ritma serdtsa na dlitel'nykh promezhutkakh vremeni [Methods of heart rate variability analysis in the long time intervals]. Moscow: Medpraktika; 2009; 172 p.
11. Fleyshman A.N. Variabel'nost' ritma serdtsa $i$ medlennye kolebaniya gemodinamiki: nelineynye fenomeny $v$ klinicheskoy praktike [Heart rate variability and slow hemodynamics fluctuations: non-linear phenomena in clinical practice]. Novosibirsk: Izdatel'stvo Sibirskogo otdeleniya RAN; 2009; 194 p.

12. Snezhitskiy V.A. Dysfunction of the sinus node: problems of diagnosis and treatment. Meditsinskie novosti 2003; 1: 22-26.

13. Mangoni M.E., Nargeot J. Genesis and regulation of heart automaticity. Physiol Rev 2008; 88(3): 919-982, http:// dx.doi.org/10.1152/physrev.00018.2007.

14. Abramochkin D.V. Migratsiya voditelya ritma $v$ sinoatrial'nom uzle i ee mekhanizmy. Dis. ... kand. biol. nauk [Migration of the pacemaker rate in the sinoatrial node and its mechanisms. PhD Dissertation]. Moscow; 2009.

15. $R-R$ interval processing using BIOPAC's HRV algorithm implementation. Application note 246. URL: http://www.biopac. com/Manuals/app_pdf/app246.pdf.

16. Vdovina N.V., Denisov A.S. Varianty izmeneniya ritma serdtsa u detey shkol'nogo vozrasta pri ortostaticheskoy probe. V kn.: Ot krizisa $k$ modernizatsii: mirovoy opyt i rossiyskaya praktika fundamental'nykh i prikladnykh nauchnykh razrabotok [Variants of heart rate alteration in school-age children using orthostatic test. In: From crisis to upgrading: world experience and Russian practice of fundamental and applied scientific developments]. Saint Petersburg; 2014; p. 34-39.

17. Gubler E.V.Vychislitel'nye metodyanaliza iraspoznavanie patologicheskikh protsessov [Computational methods in the analysis and recognition of pathological processes]. Leningrad: Meditsina; 1978. 